\title{
Research on the intelligent management system of rural land circulation based on GIS
}

\author{
Hui LIU \\ Huaibei Normal University School of Economics, Huaibei, Anhui
}

KEYWORD: Rural Land Circulation;GIS ;Intelligent Management System;Land Administration

\begin{abstract}
With the rapid development of social economy, the rural land management mode of China's extensive is difficult to adapt to the requirement of rapid development, People have a further understanding of the importance of the rural land circulation, and national policy has also been adjusted for the use of land. Land transfer has a very important role in the upgrading of industrial structure and the growth of rural economy. In this case, the land circulation urgently needs advanced technology, and the geographic information system GIS has been playing an important role since entering the Chinese social economy. There is no doubt that this technology can also provide support for the construction of new socialist countryside. In the process of land circulation, GIS can realize the unified management of the data of different classification such as space, attribute and so on ,to achieve data analysis and statistics more quickly. GIS can provide a great convenience and effective analysis for land planning and management personnel to obtain accurate land data , Especially for the rural land circulation intelligent management system that based on GIS can improve the work efficiency of the new rural construction land circulation and management.
\end{abstract}

\section{GENERAL INSTRUCTIONS}

Twentieth Century 50 60 years, the land information management system origin in the western. It can be said that the emergence and development of land information management system directly changed the way the world land and Resources Department of land information management, so that the land management into a new era. Land development in China is relatively late, until 1998 the establishment of a national land consolidation center, to 2001 carry out land consolidation and sustainable utilization of land resources "project, the country began the introduction of western experience and technology of land management, efforts to improve the whole level of land use, and strive for the rational use of land resources in china.

However, in the new situation of land transfer under the traditional management mode by the departments of land and resources management is facing great challenges: the pure management rely on artificial management is low level of information, and the degree of land transfer will inevitably produce large amounts of information storage and recording. This management mode has intensified the contradiction between the land use. With the rapid development of information technology, geographic information system GIS is more well known, many experts and scholars apply GIS technology to the intelligent management of construction land circulation research, put forward many new academic achievements, such as the famous scholar Zhu Hongbo put forward the innovative design in land resource management information in the database by using GIS technology;Dong Xiaosheng studied the application of GIS technology in some small land planning system. In these studies, the traditional land and resources information collection, management and dissemination of the model has changed dramatically.Now China's land information management system, has developed into a comprehensive, multi-level, organic integration of intelligent management system, providing support for the daily office and land services.

\subsection{Land Circulation Intelligent Management System}

Land transfer system refers to the extensive rural land use is difficult to maintain economic development and land requirements, according to the national policy adjustment of rural land system, In accordance with the law to allow farmers to transfer land contract and management rights, the principle of voluntary payment, can land subcontract, lease, exchange, transfer, share 
cooperation mode, forming various forms of reasonable scale of operation. This land transfer system has a very important role in promoting rural economic development, accelerating the upgrading of rural land industrial structure, optimizing the allocation of resources, and realizing the rational economic management of land resources.

In this case, the land as a non renewable scarce resources, has a reasonable use of the important significance in the land transfer system. In recent years, due to the unreasonable land planning and other reasons, often resulting in waste of land resources in rural areas. Therefore, the land circulation system urgently needs the advanced information management system to carry on the technical support. GIS, full name is called the geographic information system (Geographical Information System), based on computer support, with information collection, storage, management and analysis of relevant data, analyze specific issues of information management system for users, has played a crucial role $\ln$ the rural land information.

The GIS-based rural land circulation intelligent management system achieved unified in the land circulation space and property data management, the rural land transfer information and data are very intuitive records,to facilitate the timely understanding of land resources managers accurate land circulation resources information, c to help managers of the collective land transfer process of systematic analysis, to provided for strengthen management and specific planning for land transfer and to promoting the rural land management information construction

\subsection{Objectives and significance of the intelligent management system of land transfer}

The general goal of GIS-based rural land circulation intelligent management system is to provide a land resource sharing platform for the vast number of users and decision-makers, constructing a visual information management system according to the information of rural land circulation , and constructing a convenient information resource management system for Land planning department of land information management, land resource planning

\section{FUNCTION REALIZATION OF INTELLIGENT MANAGEMENT SYSTEM OF RURAL LAND CIRCULATION BASED ON GIS}

The realization of the system function, generally depends on how to use a good system interface to meet the user interaction. GIS intelligent management system based on rural land circulation, in order to facilitate the transfer of rural land information management and decisionmaking, to meet the contractual right of rural land circulation and management, has a certain particularity in the actual use of the function.

\subsection{Function basis}

According to the special provisions of the state on the circulation of rural land system, rural land circulation and transfer rights and other business changes can be realized analysis of the specific function requires the construction of professional system of rural land circulation and the circulation of information database. Therefore, The intelligent management system needs to establish the database according to the national land laws and regulations,such as 《Land Administration Law of the People 's Republic of China》, 《Investigation on the Contractual Operation Right of Rural Land》, 《The specification of the registration database of rural land contracting right》and 《The Rules of Key Elements of Rural Land Contractual Management Rights》 


\subsection{Main function analysis}

After the establishment of the intelligent management system of rural land circulation based on GIS, the management system based on the independent land circulation information and the resource database can complete the following 6 aspects of functional support:

(1)Data editing: It can transform the different geographic information data and the land transfer information data. Through editing intelligent management system, the data of different format import and automatic relevance, ensure mutual conversion between different kinds of data template, to achieve a complete unity and accuracy of land transfer information in the content and time and space.

(2)Data processing: It can carry out Information data that transmission to intelligent management system and to realize the editing of graphics, modify and extract the attribute data, and show the data in an intuitive way according to the system software.

(3)Data management: It can set management requirements to investigate and analyze the rural land transfer information,according to the relevant standards and requirements of the land transfer system. Completion of the land information data storage, as well as the management of the entire database,and conducive to the operation of the computer, deepen the understanding and planning of the user

(4)Inspection and analysis of the data: According to the relevant standards and requirements of the land transfer system, the inspection of the relative rules, the validity check of the sentence, and other inspection in the intelligent management system,to examine and analyze the integrity, accuracy and logic of the information in the database, in order to extract the relevant topological characteristics, analyze and explain the problems in the process of land transfer.

(5)Data query: It can query the information according to the data of rural land transfer information database, through the specific query function, according to different regions, towns and other conditions for the transfer of different land , Including query land information, the transfer of information and other related content.

(6)Data output to assist decision making: the user can output the relevant information of the land transfer in the form of a report or drawing in order to meet the needs of the public.

\section{DESIGN OF THE INTELLIGENT MANAGEMENT SYSTEM OF RURAL LAND CIRCULATION BASED ON GIS}

Applying the GIS technique to the circulation of rural land construction, is to realize the professional management of land management rights transfer of information and data, information and standardize the rural land transfer to achieve unified management, make a contribution, make a new exploration for the development of new rural construction and new socialist rural informatization.

\subsection{An overview of system design based on requirements}

The intelligent management system of rural land circulation, is based on the realization of information management platform for the transfer of rural land demand, aims to reflect and solve the user's actual requirements and provide basis for planning, rational allocation of land resources for the following countries. According to the specific content of the rural land circulation system and management, the specific requirements of the intelligent management system of land circulation need to be solved are summarized as follows. 
(1)Rural land transfer information management workh a lot has of space, property data appear, For example, the current situation of land transfer and the future planning of the information, the relevant information of arable land, idle residential information, etc. Intelligent management system should be able to carry on the unified organization plan and the analysis to the different type of data, in order to improve the management of the land circulation information and the specific planning ability. In accordance with the law to allow farmers to transfer land contract and management rights, the principle of voluntary payment, can land subcontract, lease, exchange, transfer, share cooperation mode, forming various forms of reasonable scale of operation.

(2)The rural land circulation intelligent information management system based on GIS technology, takes full advantage of the GIS visual management, realize the reasonable distribution of the status quo on the land transfer analysis, idle residential analysis, farmland crop analysis, makes the management of rural land circulation situation dynamic monitoring, rational planning and use of land resources.

(3)Rural land circulation intelligent information management system should have the integrity of the land transfer information management functions, providing comprehensive data management and query, statistics, analysis and data output, and other functions.

(4)Rural land circulation intelligent information management system should have a good user interface, to ensure safety management and rights management, improve the system's experience and security experience.

\subsection{System structure and function module design}

The intelligent management system of rural land transfer is based on the planning of the rural land circulation system and the policy of the national land law. GIS technology based on geographic information system is the use of system and structural design to provide services,in the process of realizing the intelligent management of rural land circulation. From the structure of the intelligent management system of rural land circulation, it is divided into three layers according to the structure of the performance level, business logic level and data level, the three structure is very independent in the system logic, the module task is also relatively clear, effectively adapt to the user's demand for intelligent management system.

According to the function module, the intelligent management system of rural land circulation integrated farmers, farmland, housing, crop farming, constructed the visualization of the intelligent management platform of rural land circulation,which is very powerful in the realization of spatial and attribute information query processing and concrete analysis. Specifically, the function of the intelligent management system of rural land circulation includes:

(1)Map management function - is mainly to facilitate users to complete the map browsing, retrieval, access and other functions.

(2)Land circulation data management function - this part is mainly aimed at the retrieval and processing of attributes and spatial data, and realizes the accurate control of the land transfer information.

(3) Statistical analysis function - this part analyzed the specific attributes of the data, so that the management of the actual situation of the land transfer, such as residential distribution, cultivated land and crop planting, easy to adjust the planning.

(4)System maintenance function - System data security permissions settings and data management functions 


\subsection{Design of system database}

Database is a very important part of intelligent management system, and the intelligent management system of rural land circulation contains many kinds and quantity of information. Therefore, the intelligent management system based on database should be a comprehensive database, can satisfy the needs of management and orderly management of basic data and data processing, attribute data and spatial data and other basic needs. The database of the intelligent management system of rural land circulation involves a wide range of information, including the current situation of land transfer, land transfer and other data and information. In order to manage the basic data of land transfer, it is necessary for the management department to effectively master the macro information of the land circulation, and to adjust the land planning. Specific database management methods have the following:

(1)Map aided management database module:the database module mainly for map function management, realize the basic operation of map and index of the current situation of rural land circulation, land resources planning map and other maps, in order to control the real data management.

(2)Land data management database module: the database module provides the attributes and spatial data query, search and information processing, in order to achieve the status of the land transfer query function.

(3)Idle housing information management database module;

(4)Cultivated land information management database module;

(5)Attribute field statistics database module: it mainly relates to data retrieval in data attribute table;

\section{SUMMARY}

The development and application of GIS technology in rural land circulation based on intelligent management system, greatly facilitates the Department of agriculture and land resources management departments to establish and improve the rural land circulation system, to ensure the land rights of farmers, standardize the process of land transfer process and reduce and has a great influence of the solution in the process of land transfer specific land the dispute. Under the support of GIS technology, the intelligent management of land transfer, to promote the management of agricultural production sector and the level of information technology, to enhance the management of land resources in the country has a significant auxiliary. Such intelligent management system provides a good reference for the rural land circulation information management in the area of economic development. The support of intelligent management system is of great significance to the realization of information construction of rural land transfer system.

\section{REFERENCE:}

[1]Xie Fang.Study on rural land circulation system[D].Xi'an:Xi'an University of Science And Technology, 2014

[2]Liufu.Legal Thoughts on rural land circulation system [J]. agricultural economy , 2005 ( 11$): 28$

[3]lirong.The design and implementation of land transfer information system [D]. Chengdu: University of Electronic Science and technology, 2010.

[4]RunFengchao.Based on the land contract management information system WebGIS technology [D]. Changchun:

[5]Chang Xiaoyan.Research on the management information system of land use planning at county level based on [D]. GIS Shandong: Shandong Agricultural University, 2005 